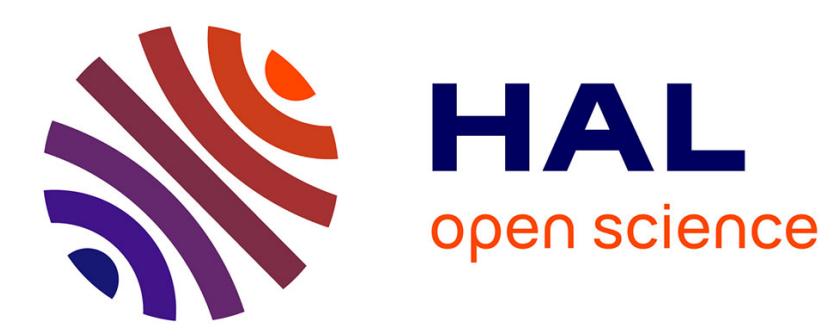

\title{
Parallel Stories: The Rise of the Far-Right Women's Movements in the 1930s and 2010s
}

\author{
Andrea Petö
}

\section{To cite this version:}

Andrea Petö. Parallel Stories: The Rise of the Far-Right Women's Movements in the 1930s and 2010s. Back to the '30s? Recurring Crises of Capitalism, Liberalism, and Democracy. Eds. Jeremy Rayner, Susan Falls, Taylor C. Nelms., pp.277-292, 2020. hal-03204910

\section{HAL Id: hal-03204910 https://hal.science/hal-03204910}

Submitted on 21 Apr 2021

HAL is a multi-disciplinary open access archive for the deposit and dissemination of scientific research documents, whether they are published or not. The documents may come from teaching and research institutions in France or abroad, or from public or private research centers.
L'archive ouverte pluridisciplinaire HAL, est destinée au dépôt et à la diffusion de documents scientifiques de niveau recherche, publiés ou non, émanant des établissements d'enseignement et de recherche français ou étrangers, des laboratoires publics ou privés. 


\title{
Parallel Stories: The Rise of the Far-Right Women's Movements in the 1930s and $2010 \mathrm{~s}$
}

\author{
Andrea Petö $1 \square$ \\ 1 Department of Gender Studies, Central European University, Budapest, Hungary
}

\section{Abstract}

The abstract is published online only. If you did not include a short abstract for the online version when you submitted the manuscript, the first paragraph or the first 10 lines of the chapter will be displayed here. If possible, please provide us with an informative abstract.

This chapter puts into dialogue the lives of far-right women in politics (intellectuals, relatives of party functionaries, administrators, artists, simple criminals) who rejected both the "conservative offer" and the leftist emancipation project in the interwar Hungary with the women participating in contemporary radical politics rejecting both the neoliberal emancipation project and feminisms. What can we learn from historical-comparative analogies with regard to far-right women's political mobilization? Using the lenses of anti-modernist emancipation and "gender as symbolic glue" in the two contexts based on testimonies of farright women activists in the people's courts after 1945 and in interviews made with contemporary far-right women activists about their motivations to join the movements, I argue that activists from both historical periods intended to create alternatives in terms of values, institutions, and symbolic systems as a critique of other gender regimes.

\section{Keywords}

Polyphore state

Interviews

Gender

Familialism

People's tribunal 
Józsefné Thoma, a medical doctor, once wrote that, "We demand for ourselves equal rights with men in the field of honor. We are aware that this means equal obligations and duties. May we refuse to accept a separation between male honor and female honor! We protest when people say that a woman's lies can be forgiven and are 'endearing', [...] and we protest when the word 'lady-speech' is dismissed with a wave of the hand" (Thoma undated: 14). Dr. Thoma set up consciousnessraising groups and helped women to gain leadership positions in 1930s Hungary.

Thoma could be celebrated as a proto-feminist if it wasn't for the uneasy facts that this quote is from educational material for women of the Arrow Cross Party, the Hungarian Nazi Party during World War II, and that Thoma was a leader in the party's women's section. One feels the same unease when reading other demands by other far-right politicians, such as the demand to end structural inequality, unpaid labor, and sexual harassment at the workplace-especially given that protection against uncertainty and harassment was extended only to Hungarian women. The Arrow Cross Party - whose short rule lasted from October 15, 1944 until April 4, 1945-formed a government with the help of the occupying Nazi forces at a moment when this party was the only political force guaranteeing unlimited access to resources of Hungary to the Germans. The Arrow Cross rule left Hungary in ruins by the spring of 1945 . No matter that the quickest deportation of 500,000 Jewish Hungarian happened during the Horthy regime, the persecution of Jews continued with local killings and forced marches to the West during the Arrow Cross rule.

Can history repeat itself today as another version of the 1930s? Are we re-living the Weimar moment? Or have we already left the Weimar moment behind us without even noticing it? In Hungary, this question emerges as attacks on reproductive rights fill the headlines and government-sponsored billboards promote motherhood and condemn abortion, while the allegedly mainstream right-wing Hungarian government increasingly adopts positions previously espoused by the far right. This contemporary discourse might suggest that a re-run is in effect, but through a comparison of Hungarian women's far-right mobilizations in the 1930s and in the 2010 s, I will demonstrate that there are more differences than similarities between the two periods. I also suggest that there is not much of a basis for optimism about the future (Petö 2009, 147-154). 
However, an analysis of these period studies will shed a light on similarities and differences as far as the emergence of anti-modernist emancipation, a backlash against the changes in women's situation after World War I and 2008 are concerned. Far-right politics offered different options for women's participation and prowomen ideas. Hilary Pilkington (2016) refers to far-right politics as a "slippery subject," as the far right creatively transforms itself by including and omitting combinations of issues depending on political opportunities. This chapter addresses a long-term blind spot in far-right research, which has just recently started analyzing the motivations and agency of politically extremist women (Köttig et al. 2016). I argue that this "slippery subject" can also transform into something fundamentally new, as is now the case.

In making a comparison of the present with the 1930s, the 1944 German occupation of Hungary and the triple crisis (financial, refugee and security) of 2008, I draw upon two distinctly different narrative sources. First, is the set of testimonies of women charged as war criminals in front of the people's tribunals after World War II in Hungary (Pető 2007, 335-349; 2014, 107-131; Barna and Petö 2015). The people's tribunals were legal institutions expected to mark the end of a dark era, though they were generally lenient toward female perpetrators because of the gender bias of the court. Still, the women's narratives presented to the court offer rare insights into Arrow Cross Party mobilization.

Based on these files, I reconstructed the motives and beliefs of several far-right women - intellectuals, relatives of party functionaries, administrators, wives, artists, and simple criminals - who supported the Arrow Cross Party. They rejected the mainstream "conservative offer" of the interwar Horthy regime (Papp and Sipos 2017) as its discourse was pushing women back to kitchen and family and it was unappealing to wage-earning and professional women. These women of the Arrow Cross also rejected the leftist emancipation project of trade unions, communists, and social democrats since they supported anti-Semitic, anti-communist rhetoric of the Horthy government which blamed Jews and communist for the loss of World War I.

My second set of data is drawn from interviews I conducted in the early 2000 s with prominent female members of the then-emerging far-right subculture: activists, members of the Parliament, intellectuals, journalists, and elected representatives in municipalities (Petö 2003). This period was the golden day of neoliberalism in Hungary under the government of the Hungarian Socialist Party. These women were not taken seriously either by their own party members or by their ideological 
opponents. When I approached them for interviews, they were surprised and proud, hoping to gain both the historical significance and visibility they lacked through the interview process. I recorded the narratives of women who were sharing their stories with me, a well-known, progressive intellectual, who they knew belonged to a different political community. In avoiding the trap of being considered as a potential convert, I occupied the position of a learner: I wanted to learn about their motivations for entering politics and the far right. By now, these interviewees have become prominent members of the political establishment of Hungary, but we still have polite small talk if we meet. I therefore consider these interviews to have been mutually beneficial, one in which the views, dignity, and agency of the interviewees have been acknowledged.

\section{Political Rights as Basis for Far-Right Mobilization in the 1930 s and Today}

After World War I, women's newly acquired right to vote forced different political parties to reconsider their neglect of women as political agents. At the same time, "woman" and especially "the new woman" (a financially independent subject who ignored patriarchal expectations) emerged as an unpredictable and dangerous element that threatened male hegemony in economic, political, and cultural spheres (Petö 2009, 48-52). Thus, far-right parties were met with a considerable challenge to shape policies on women's issues. Besides the changes caused by the lost war and the failed revolutions, the Horthy regime also had to adapt to the transformations in gender politics.

It was in 1920 due to the armistice with the Entente Hungarian that women received limited suffrage but at same time women's employment rate showed a steady increase. But while $40 \%$ of the population was enfranchised in 1921, the percentage dropped to $27 \%$ by 1930 , which contributed to major political problems such as increasing political radicalism. The conservative political elite of Horthy's Hungary were caught in a trap, as their conservative, antidemocratic political system was challenged both from the left by the social democrats and from emerging far right supported by Nazi Germany.

The power and visibility women had gained during World War I was increasingly erased. During the interwar period, women's suffrage was restricted and attempts were made to restrict women's enrollment in higher education (Petö and Szapor 2004, 172-182). The change was striking: within a decade, women were working as doctors, scientists, and teachers, in places where female employees had been previously unimaginable. At the same time, a new concern emerged: the threat of 
workplace discrimination. According to a 1938 survey conducted, $60 \%$ of Hungarian women with higher educational degrees had experienced workplace discrimination in some form (Papp 2004, 75). The Arrow Cross Party offered an anti-modernist emancipatory project which quickly became very popular among employed women.

This was the backdrop against which the Arrow Cross Party broke onto the Hungarian scene. Far-right political parties had steady and growing support in various electoral districts from 1920 onwards. The Arrow Cross Party, after uniting different far-rights parties and movements, was the only political force which had a political offer on the right to women who were employed, ambitious, and active. The party struggled to cope with the fact that its official gender policy, which was too similar to the "conservative offer" of the Horthy regime, was rejected by many women who otherwise sympathized with the party's ideology and who would have been useful party members. As a response, the party provided political space for the realization of female autonomy by promoting the cult of ancient (pre-Christian) Hungarian women as equal to their men. This is why many women joined the Arrow Cross; they were driven by a rejection of the existing conservative, patriarchal order where they were confined to the private sphere as mothers and wives. The "slippery subject" mobilized women, with some districts having $30 \%$ of members as women.

The narrative testimonies of women at the people's is one of the very few sources describing the motivations of women who joined the Arrow Cross Party. These testimonies represent a mediated truth, as these women fine-tuned and performed their stories in a court where a proper testimony could lead to acquittal while a wrong one could lead to a harsh sentence. The stories presented at court by women about their motivations to join the Arrow Cross Party mostly fitted into a normative far-right image of femininity, an image based on motherhood. They were rewarded with lighter sentences than those who proudly shared social and political agendas for joining the Arrow Cross Party.

The complexity of women's political and economic motives within women's farright political mobilization is present in both the 1930s and the 2010s. For example, in the 1930s the radicalization of women prompting their eventual political mobilization was often connected to their employment experience. Those who, at great individual cost, managed to graduate from university were confronted with discrimination in the workplace (Petö 2008, 63-83). Their political radicalism was a reaction to rigid social hierarchies, to gender discrimination, and to poverty, best 
exemplified by the case of first generation of Hungarian female medical doctors like Dr. Thoma. As a political force, the far right promoted a form of citizenship that guaranteed active political agency to women in an otherwise conservative political regime founded on gender-based exclusion and a cult of domesticity. Furthermore, statements made by far-right women at the people's tribunal's hearings often revealed individual economic needs as motives for stealing Jewish property.

In 1989, liberal elites in Central Europe shared the optimism of transnational institutions, offering voters a business-as-usual approach to modernization which privileged policies over ideas. Gender studies scholars were less enthusiastic and more critical about the price women paid for the post-1989 transition as far as unemployment, pay gap, and segregation were concerned (Fodor and Horn 2015; Petö 2015). Many women political extremists I interviewed described the post-1989 neoliberalization of Eastern Europe as a failed promise. Their stories followed more or less the same line: they expressed concerns about the increase of poverty and discrimination and interspersed them with anti-elitist slogans. The stories of compensation for loss were present in interviews I made in the early 2000s. Women joining the far-right movements after 1989, even those who did not come from families who suffered persecution during communism, unanimously narrated their family stories before 1989 as lists of losses. After 1989, anti-communism became the dominant narrative frame which was conveniently open for nearly everybody. But the interpretation and presentation of women's political-economic experiences have to be viewed in light of waxing global neoliberalism.

The triple crises of 2008: financial, security, and migration made the already visible cracks of the neoliberal world order visible. On the individual level, both left and right voters were suffering from the same factors, but the leftists due to the trap that these were the leftist parties which promoted neoliberal policies in Eastern Europe are not in a position to criticize neoliberalism. As in the 1930s also in the early 2000 s, the leftist critic of capitalist production was not an option, and this necessarily pushed women toward the right-wing political radicalism.

"Neoliberal neopatriarchy" (Campbell 2013) had dire consequences for equality politics globally. While it might ostensibly support a narrow and market-oriented version of gender equality, it has simultaneously dismantled the welfare state, undermined social solidarity, and rejected structural reforms needed to reach genuine equality. The result is a system which accepts some token women in positions of power, but leaves masses of women behind. As a consequence, 
progress in reaching gender equality has stagnated in the last two decades, adding to a general feeling of frustration and disappointment with equality politics in general. This has led many women to doubt the sincerity of the equality paradigm itself (especially within the paradigms of neoliberal policy) and to seek alternative forms of empowerment in anti-modernist and nationalist projects such as familialism or far-right extremism (Petö 2011). Similarly, Nazi and fascist parties were able to attract considerable support by women voters in the interwar years as they offered support, security, and economic possibility in a society with growing inequalities.

AQ3

AQ4

In literature covering interwar Europe, there is consensus about the trigger moment for the rise of far-right movements: the 1929 financial crises. How might the triple -financial, security, and "refugee" — crises of 2008 be considered as our era's trigger moment? As Berezin demonstrated in depicting the rise of the National Front in France, the process of European political, economic, and cultural integration, guided by the neoliberal doctrine, resulted in a gradual dismantling of European institutions and re-embedded people into their national polity frameworks (Berezin 2009, 2013, 241). The consequent weakening of citizens' political, social, economic, and cultural security leads to insecurity and fear, which has been further boosted by the triple crisis of the European project-financial, security, and refugee - that revealed cracks in the foundations of the post-national world. Within a landscape largely devoid of sources of security on the European level and a lack of electable left-wing alternative projects, these crises created a culture in which rightwing answers to the emergent problems were supported by mainstream politicians and eventually began to appear "normal" (Berezin 2013, 242). Similar dynamics were at play during the 1930s, except there was a leftist alternative at that time: the Stalinist Soviet Union. It took some years and revolutions killed by Soviet tanks in 1956 and 1968 for this alternative to become finally discredited. At the moment, alternatives are not presented as one country but rather as alternative streams and subcultures within countries. The role of transnationalism is increasing as the importance of locality and local resistance is increasing.

\section{Political Infrastructure: Organizations and Media Presence}

Discussing similarities and differences in women's political activism between the 1930s and today has often escaped the attention of historians partly because 
women's activity has not been limited to party politics, but also manifest at informal gatherings such as tea parties and other "alternative public spaces" which leave no written documents behind (Pető and Szapor, ibid.). This is especially true for supporters of non-mainstream politics like far-right extremisms. The arenas in which political citizenship has been exercised are also definable in terms of class: only exceptionally did women get close to the formal decision-making level. In the Arrow Cross, however, wives of party leaders ran an important informal network which played a significant role in the distribution of jobs and sharing information about employment vacancies.

Today in Hungary the institutional network of far-right women and the identity, principles, and future political vision of the far-right women's movement remain "under construction." Women can create a space for promoting their own agenda if they do not question male hegemony. This agenda incorporates a variety of demands such as the formation of a strong, protective, responsible state and offering welfare provisions (originally leftist planks). They mobilize women along cultural and symbolic lines related to identity issues. Members share their views on various issues, even those concerning intimacy, sexuality, or behavioral and dress codes. They reach back (without any critical reflection) for symbols and discourse patterns to pre-1945 Hungary, which is interesting in the framework of resistance to communism. The resistance to communism presents an alibi not to come into terms with Hungary's role as an ally of Nazi Germany in World War II and murdering 600,000 of its citizens (Petö 2017, 41-51). This anachronistic revival of pre-1945 women's mobilization patterns contributes to a perception that there is a continuity and similarity of the present with pre-1945 ideas, movements, and patterns.

\section{Troubling Complexity: The "Catch All” Mobilization}

Historical analogies are selective and simplifying, and they tend to render certain actors invisible. This is especially true for the "slippery subject," as far-right mobilization is a "catch all" mobilization. Based on my analysis of the people's tribunal files, women associated with the Arrow Cross Party formed four separate yet heterogeneous groups (Matthée and Petö 2008, 285-303). The first group consisted of women who had already joined other far-right parties in the 1920s. They were mainly disillusioned white-collar women, such as typists and bookkeepers. Many of them had come to "truncated Hungary" (as the country was referred to following the 1920 Treaty of Trianon, according to which Hungary lost two-thirds of its pre-World War I territories) as ethnic Hungarian refugees from areas ceded to the successor states of Austria-Hungary after 1919. For these 
women, the newly founded Arrow Cross Party offered a framework for social integration in their chosen country. Often single, these working women believed that their professional and social mobility had been hindered by a conservative political regime with its emphasis on women's place in the home. For this reason, they supported radical political solutions, in particular those offered by the far right.

The second group was comprised of lower-middle-class or working-class women who had committed criminal acts during World War II. They exploited the Holocaust to take revenge and to "redistribute" social goods. This group included some mentally ill women as well as others who clearly suffered from psychological problems. These women formed the largest group of defendants at the People's Tribunal.

The third group consisted of rebellious and revolutionary women from middle-class or upper-middle-class backgrounds. They were educated, wore men's clothing, and rode horses just like men. Although these women appeared to be emancipated, rejected patriarchy, and had gained access to areas formerly closed to their gender, they were marked by anti-modernism as their identity had been formed against a European modernity that brought only inequality and gender discrimination to them. Therefore, they reached for examples of strong women from Hungarian history from the time of the conquest of the Carpathian Basin in the tenth century, celebrating their autonomy and independence in a pagan tradition.

The fourth group was the best-known and most visible in the public discourse. They were female family members of Arrow Cross leaders. Most were from middle-class or upper-middle-class backgrounds, but unlike the third group, they had no professional aspirations; their public identity was that of "wife" or "supporter" to a husband or relative. They often ran supporting businesses of the far right such as publishing, ethnic clothing, and social and media enterprises.

Likewise, women who founded far-right organizations during the 2000s when farright politics were outside of the mainstream had various social backgrounds and career trajectories. Those who had a chance for professional careers came from families connected to the new political elite, had grown children, or were childless. Nearly all four groups of far-right women from the interwar years are present today except the third one. These women found a space in far-right politics to live outside of conventional gender norms of the Horthy regime. In today's politics, these radical women find a political space in a progressive and inclusive subculture. 
Women activists in both periods aimed to create a livable and desirable alternative consisting of values, institutions, and symbolic systems as a form of critique of oppressive gender regimes. Their agendas cut across traditional right/left political cleavages to challenge an existing party system. The way they envisioned these alternatives was a reflection of the weaknesses and mistakes of their era's progressive politics. And, of course, far-right politics today (as in the 1930s) has been unquestionably increasing its electoral support during the last decade. Still, neither a structural explanation (based on the triple crises of 2008, allegedly similar to the 1929 crisis) nor the claim that a silent majority is gaining a voice, nor the Deleuzian explanation that a quest for security acts as a driving force toward fascism is fully adequate for explaining the gendered modus operandi of today's illiberal states (Grzebalska and Petö 2018). Furthermore, I argue that thinking in historical analogies is helpful but limited and may delay the recognition of today's true political challenges.

\section{From a Failed State Capture to a Successful Polypore State}

The main difference between the situation 1930s and today lies in the relationship and the functioning of the state to the public. The Arrow Cross Party, while enjoying strong support among the civil servants, especially by transport workers and the police, was a despised subculture which failed to take over the state during the last months of World War II when the Red Army was approaching the country. But now, we are witnessing a quiet and successful process of building up a new form of state. And this is the fact which makes the present situation worse than the 1930s. With Weronika Grzebalska, I argue that illiberal European Union member states can best be understood as majoritarian nationalist responses to a systematic preponderance of globalized neoliberal democracy which has shaped relationships between individuals and the state during the last four decades. Illiberal states are reaching back to the third way ideology of the 1930s: they offer what appears to be a desirable, viable, and livable alternative to established ideologies of conservatism and liberalism while challenging international socialism understood as the progressive European tradition.

As far as the inadequate response from mainstream politics to economic crisis and with regard to the lost promise of women's suffrage, the failures of conservative politics led to the radicalization of the mainstream in interwar Europe. In following contemporary mainstream leftist responses to the refugee crisis, it is difficult to trace where political extremism begins. Preexisting fears reframed what could be 
acceptable as policy, and as a reaction, extreme discourses and ideas became normalized with either explicit mainstream support or simple non-action. The weak commitment of semi-peripheral elites and the public to the liberal system contributes to a profound institutional crisis undermining the legitimacy of democracy.

George Mosse in his oft-quoted Masses and Man wrote about fascism as an "amoeba-like absorption of ideas from mainstream of popular thought and culture, countered by the urge towards activism and taming" in addition to a ruthless dismantling of the liberal parliamentary order (Mosse 1987, 183). This definition depends on the understanding of the "slippery subject" as its modus operandi. With Grzebalska, I suggest using the biological metaphor of the polypore to shed light on the crucial differences between the 1930s and today.

In terms of its gendered modus operandi, an illiberal regime can best be understood as a polypore state, a parasitic organism, which feeds on the vital resources of its host while contributing to its decay, and only produces a fully dependent state structure in return (Grzebalska and Petö 2016). On the one hand, illiberal "polyporism" involves exploiting and appropriating various aspects of the European liberal democratic project including but not limited to its institutions, procedures, concepts, and funding opportunities. Contrary to popular belief, Hungarian FIDESZ is not interested in leaving the EU or rejecting its basic concepts as human rights or gender equality. Rather, they wish to exploit funding and political opportunities offered by the EU while pursuing their own political agenda.

\section{AQ5}

On the other hand, "polyporism" involves the illiberal regime divesting resources from those it considers the beneficiaries of the "corrupt liberal post-communist system"- the already existing human rights and civil society sector in order to transfer those resources to its own base to secure and enlarge it. Moreover, just as the polypore usually attacks already damaged trees, illiberals rise to power primarily in the context of weak state institutions, divided progressive parties, and failing liberal democratic projects. In the polypore state, far-right extremism is incorporated to legitimize and to maintain the very existence of the polypore.

The operation of the illiberal polypore state is gendered, an aspect which escaped the attention of scholars analyzing recent developments. The illiberal polypore state is working with securitization as public policy discourses are becoming security issues. The imagined threat by migrants, gender studies scholars, or George Soros is a constitutive part of the governance. The second aspect is familialism where 
women are no subjects of policy making only as members of a family unit. And last, it is constructing alternative NGOs that mirror existing institutions with state funding.

I argue that because of these three gendered aspects of the polypore state, illiberalism should not be perceived as a revival of authoritarianism but rather as a new form of governance developing out of previous democratic concepts and institutions. This new form can be better understood by going beyond a routine comparative analysis of political systems along the East-West divide to instead trace the gradual sociopolitical developments in these countries while placing them in the context of broader global processes. While post-communist democracies have their own sociohistorical legacies, the fact that illiberal tendencies are increasing all across Europe suggests that they should be viewed as local symptoms of broader structural failures of the European (neo)liberal democratic project, a dark legacy of Europeanization in its current form (see Grzebalska 2016).

\section{AQ6}

In interwar Europe, Nazi Germany and fascist Italy were presented as success stories until their victorious military campaigns lasted that gave legitimacy to farright activism in Hungary and elsewhere. Presently, Russia and Turkey are discouraging examples as far as economic potentials and way of life are concerned, besides both countries acted as occupying forces for a time in Hungarian history so selling political alliances with the is politically difficult. The game changer in history of anti-liberalism has been that official US foreign politics and Christian conservative forces have started to support the anti-human rights trend, movements so far only represented by Russia and Turkey with funding and political influence (Fitzgerald and Provost 2019).

Certainly, the illiberal polypore state will be with us for a longer period as the life energy and ideas stemming from the tree give its livelihood therefore its vital interest of the polypore state to keep the tree alive up to a certain and controlled limit. Thoma joined the Arrow Cross Party as she found space for her political ambitions of fighting for women's rights and social justice in a racist and antiSemitic party. The failure of the leftist political forces to have a viable, livable, and desirable political offer for many women is definitely a similarity between the 1930s and today.

\section{References}


Barna, Ildikó, and Andrea Pető. 2015. Political Justice in Post-WWII Budapest. Budapest: CEU Press.

Berezin, Mabel. 2009. Illiberal Politics in Neoliberal Times: Culture, Security and Populism in the New Europe. Cambridge: Cambridge University Press.

2013. "The Normalization of the Right in Post-Security Europe." In Politics in the Age of Austerity, edited by Wolfgang Streeck and Armin Schäfer, 239-261. Cambridge, UK: Polity.

Campbell, Beatrix. 2013. End of Equality. London and New York: Seagull Books.

Fitzgerald, Mary, and Claire Provost. 2019. "Revealed: Trump-Linked US Christian 'Fundamentalists' Pour Millions of 'Dark Money' into Europe, Boosting the Far Right." OpenDemocracy, March 27. Last accessed April 1, 2019. https://www.open democracy.net/en/5050/revealed-trump-linked-us-christian-fundamentalists-pour-mi llions-of-dark-money-into-europe-boosting-the-far-right/?fbclid=IwAR03p6A-ngov skQcWXUxOQhrafRHLXJCc7GRhrpDclUIIGAFKY feRa_s2U .

Fodor, Éva, and Horn Dániel. 2015. “'Economic Development' and Gender Equality: Explaining Variations in the Gender Poverty Gap After Socialism. ” Discussion Papers 2015/19. Budapest: Hungarian Academy of Sciences, Institute of Economics, Centre for Economic and Regional Studies. Accessed February 20, 2016. http://econ.core.hu/file/download/mtdp/MTDP1519.pdf .

Grzebalska, Weronika, and Andrea Petö. 2018. "The Gendered Modus Operandi of the Illiberal Transformation in Hungary and Poland." Women's Studies International Forum 68 (May-June): 164-172.

Köttig, Michaela, Renate Bitzan, and Andrea Petö, eds. 2016. Gender and Far Right Politics in Europe. Basingstoke: Palgrave Macmillan.

Matthée, Zonneke, and Andrea Pető. 2008. “A 'kameraadskes' és a 'testvérnők': Nők a holland és a magyar nemzeti szocialista mozgalomban: motiváció és akarat" ["Kameraadskes' and 'Sisters': Women in the Dutch and Hungarian NationalSocialist Movements: Motivation and Agency”]. In Határtalan nök: Kizártak és befogadottak a nöi társadalomban, edited by Eszter Zsófia Tóth and Boglárka Bakó. Budapest: Nyitott Mühely. 
Mosse, George. 1987. Masses and Man. Detroit, MI: Wayne State University Press.

Papp, Barbara. 2004. A diplomás nők Magyarországon. A Magyar Női Szemle (1935-1941). Szakdolgozat, ELTE.

Papp, Barbara, and Sipos Balázs. 2017. Modern, diplomas nö a Horthy-korban [Modern, University Graduate Women in the Horthy Period]. Budapest: Napvilág Kiadó.

Pető, Andrea. 2003. Napasszonyok és Holdkisasszonyok: A mai magyar konzervatív nöi politizálás alaktana [Sun Women and Moon Girls: The Basics of Contemporary Conservative Female Politics]. Budapest: Balassi.

- 2007. "Problems of Transitional Justice in Hungary: An Analysis of the People's Tribunals in Post-War Hungary and the Treatment of Female Perpetrators." Zeitgeschichte 34 (3-4): 335-349.

2008. "The Rhetoric of Weaving and Healing: Women's Work in Interwar Hungary, a Failed Anti-Democratic Utopia." In Rhetorics of Work, edited by Yannis Yannitsiotis, Dimitra Lampropoulou, and Carla Salvaterra, 63-83. Pisa: University of Pisa Press.

- 2009a. "Arrow Cross Women and Female Informants." Baltic Worlds 2 (34): $48-52$.

. 2009b. "Who Is Afraid of the 'Ugly Women'? Problems of Writing Biographies of Nazi and Fascist Women in Countries of the Former Soviet Block?" Journal of Women's History 21 (4): 147-151.

— 2011. "Anti-Modernist Utopia in 'New Europe': Protest, Gender and WellBeing." In Transforming Gendered Well-Being in Europe: The Impact of Social Movements, edited by Alison Woodward, Jean-Michel Bovin, and Mercé Renom, 83-96. Farnham: Ashgate.

2014. "Gendered Exclusions and Inclusions in Hungary's Right-Radical Arrow Cross Party (1939-1945): A Case Study of Three Female Party Members." Hungarian Studies Review 41 (1-2): 107-131. 
Gender Movements.” Eurozine, July 31, 2015. http://www.eurozine.com/articles/20 15-07-31-peto-en.html .

. 2017. 'Revisionist Histories, 'Future Memories': Far Right Memorialization Practices in Hungary." Perspectives on European Politics and Society 1: 41-51.

Petö, Andrea, and Judith Szapor. 2004. "Women and the 'Alternative Public Sphere': Towards a New Definition of Women's Activism and the Separate Spheres in East-Central Europe." NORA The Nordic Journal of Women's Studies 12 (4): $172-182$.

Pilkington, Hilary. 2016. Loud and Proud: Passion and Politics in the English Defense League. Manchester: Manchester University Press.

Szolgálati utasítás (Party order) 25 April 1940. Archives of Institute of Political History, 685.f. 1/4.

\section{AQ7}

Thoma, Józsefné. A hungarista nö hármas feladatköre [The Hungarist Woman and Her Three Areas of Duty]. Manuscript. Archives of the Institute for Political History, 685.f. $1 / 4$.

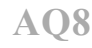

